\title{
The Printing of the Cree Bible
}

Joyce M. Banks

IN MARCH OF I849, A FEW MONTHS BEFORE HE WAS CONSECRATED FIRST Lord Bishop of Rupert's Land, David Anderson ${ }^{\mathrm{I}}$ received a letter from the Church Missionary Society (CMS) advising him that 'the primary object' in the new missionary diocese would be 'the translation of the Scriptures into Indian languages and the printing and dispersing of them. ${ }^{\prime 2}$ His mandate was a clear expression of the CMs's printing and publishing policy. Of the fifty-six titles printed for the use of the CMs in Rupert's Land between I 849 and I864, the year in which Anderson left his see, twelve were scriptural translations. The British and Foreign Bible Society (BFBS) printed six of these in London for the CMS; the most important was the Cree Bible, which appeared in three parts: the New Testament of 1859 , the Old Testament of I $86 \mathrm{I}$, and the New Testament of I 862. The last two are usually found bound together into what is commonly called 'the complete Cree Bible.'

The successful achievement of the 'primary object' identified for the diocese by the CMs depended not only upon the translation, printing, and distribution of the scriptures, but also upon the ability of the Indians to read the books they received. All scriptural translations prepared during the period examined were made into the Cree language. All of the Indians in Rupert's Land were not Cree, but most comprehended the Cree language, since it had been the trade language there for generations. The translations were expressed in the syllabic characters devised by James Evans and introduced into Rupert's Land by him, and by other missionaries of the Wesleyan Missionary Society (WMs), during the I840s. By I859, when the first edition of the New Testament was printed, the syllabic system was widely used in the diocese since the Indians learned to read the syllabic characters with relative ease. Few could read the roman alphabet.

The Diocese of Rupert's Land was vast; it extended from the East Main of Hudson's Bay to the Rocky Mountains and from the Arctic waters to the American border. By I 859 some forty thousand Indians were thought to be

The text of this paper was given at the 38 th Annual Meeting of the Bibliographical Society of Canada at Winnipeg, Manitoba, on June I 5 I 983. 
living in this huge area. ${ }^{3}$ This estimate corresponds with that published by the Hudson's Bay Company ( $\mathrm{HBC}$ ) in I 859 when the Company reported on the census of Indians in its territories. ${ }^{4}$ However, the estimates of the native population published by scientific expeditions which visited Rupert's Land suggest that there were far fewer Indians there, noting that the HBC counted all those who visited the trading posts, and many family bands visited more than one post in a season. During most of Anderson's episcopate, Anglican missionary efforts focused on an area of about fifteen hundred miles by eight hundred miles encompassing the Districts of Red River, Fairford, Cumberland, English River, York, and Moose Factory. In this region there were, at that time, probably about eighteen thousand Indians among whom the Anglican, Wesleyan, and Roman Catholic missionaries were gradually extending their influence. ${ }^{5}$

Both the Anglicans and the Wesleyans had laboured for many years to translate parts of the Bible into the Cree language. The impetus to have the complete Bible printed came from Anderson. In I 856 he discussed with the BFBS the possibility of publishing the New Testament to be followed by the Old Testament. ${ }^{6}$ It was to have been a joint undertaking of the CMs and the WMS, and Anderson wanted to convene a committee of missionary translators to finish the work. However, a complete translation had been prepared. Significantly, it was in the possession of William Mason who had been for several years in the service of the wMs as missionary-printer at Rossville before entering the service of the CMS in 1854 . This translation was that of Henry Bird Steinhauer and John Sinclair of the wMs. ${ }^{7}$ Mason and his wife, Sophia Thomas Mason, had been for several years refining and polishing this work. Mason's journals include regular entries describing their translation labours and progress. The role of Sophia Thomas Mason was of utmost importance since she was the better linguist of the two. The country-born daughter of Dr. Thomas Thomas, Governor of Red River, and a woman of the country, her Cree was faultless. Mason, on the other hand, took a Cree lesson almost daily, and deferred to his wife's superior knowledge of the Cree language in their translational work. ${ }^{8}$

Mason was sent to London by Anderson in the autumn of 1858 to see this translation through the press. On I9 October I 858 the CMs formally asked the BFBS to print an edition of five thousand copies of the Cree New Testament in syllabic characters. ${ }^{9}$ The following day the General Committee of the BFBS resolved to undertake the task. ${ }^{\text {IO }}$ The Depository and Printing Sub-Committee of the BFBs was responsible for all of the technical aspects of having translations printed and bound. By 30 October that SubCommittee had received an estimate for the cost from the printer, William Mavor Watts. He offered to compose the book, at twenty-four pages to the sheet, for £3.I.o per sheet, plus 5/- per ream for presswork. A discount of 


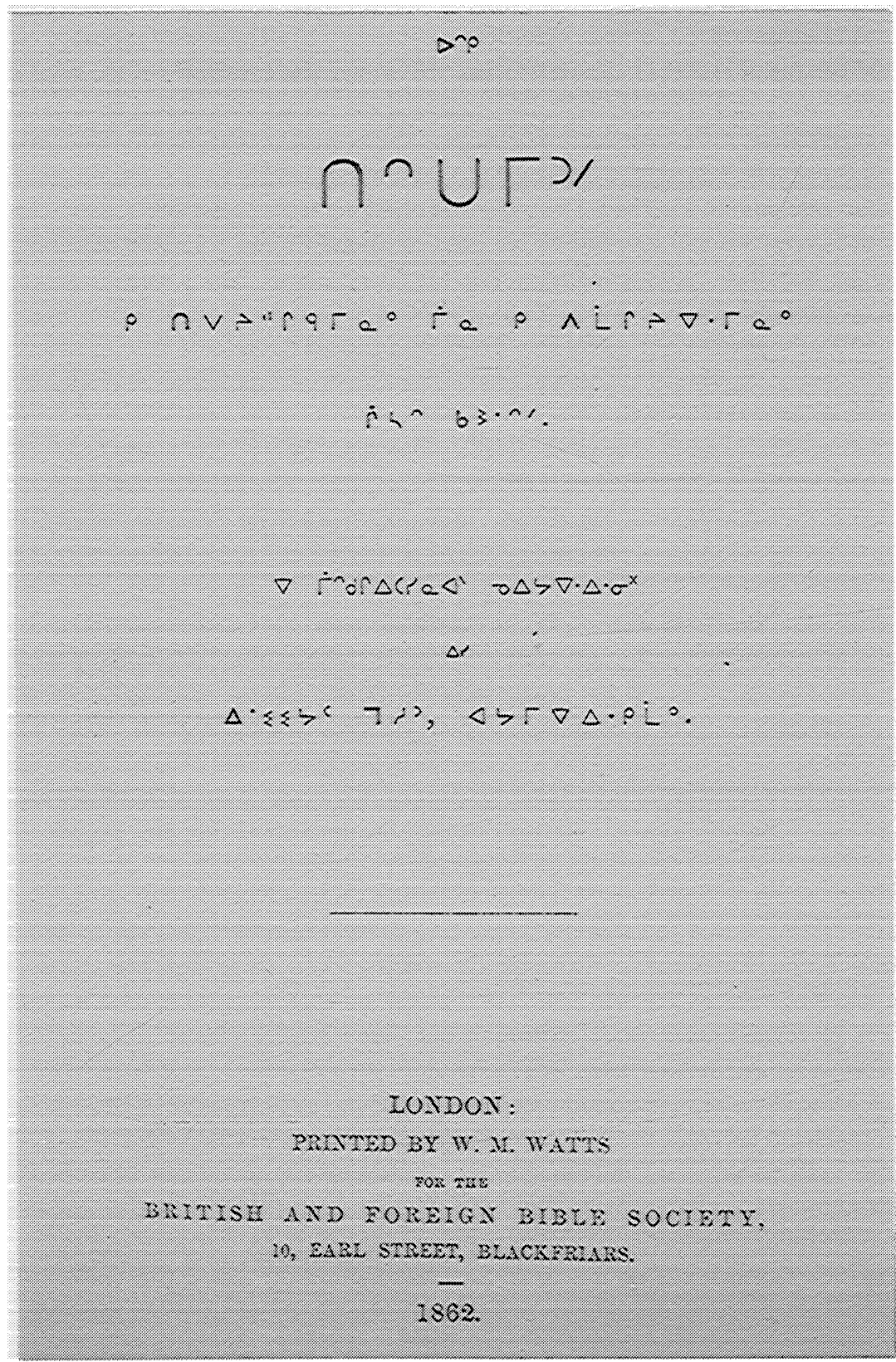

Title page of the Cree New Testament ( I 862). 


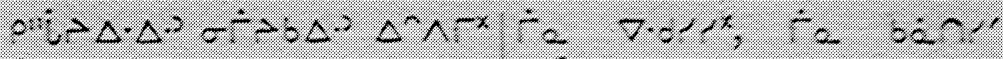
זेc $<$ ¿ेंx. $\langle i \dot{x} ;$

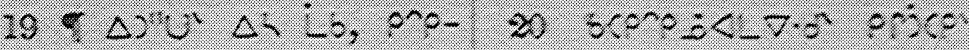

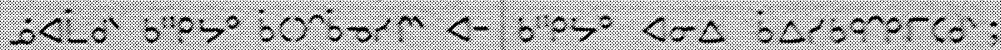

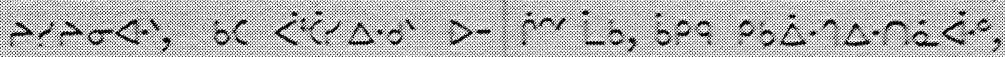

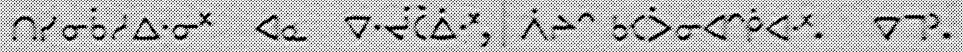

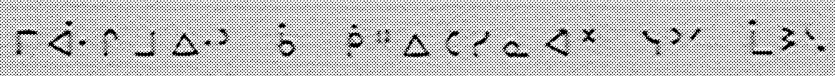

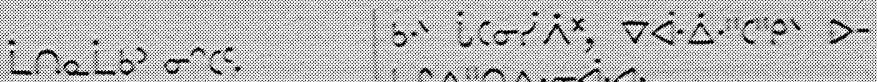
$-\wedge \Delta " n \Delta \cdot \sigma<\cdot<$.

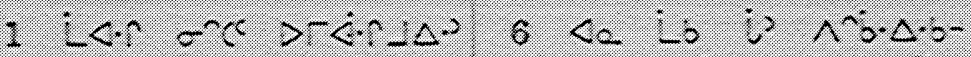

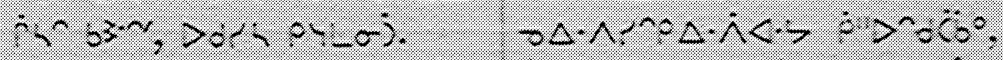

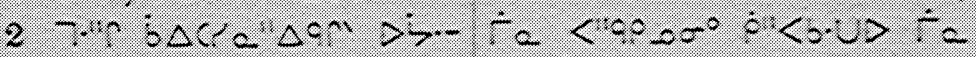
rc $\Delta \cdot\rangle_{\sigma}<\cdot$, in,

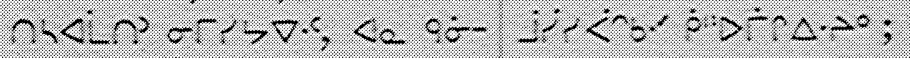

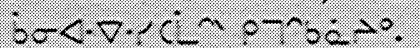

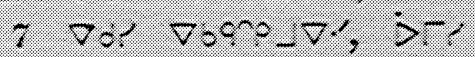

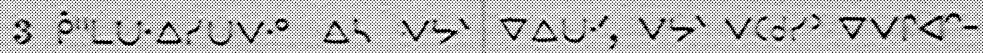

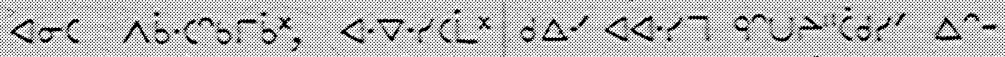

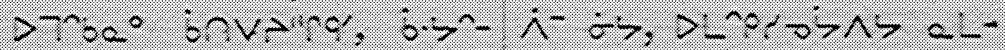

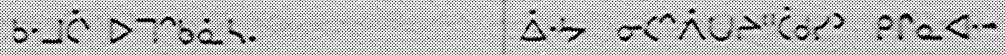

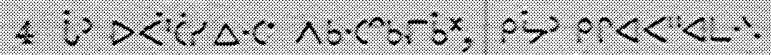

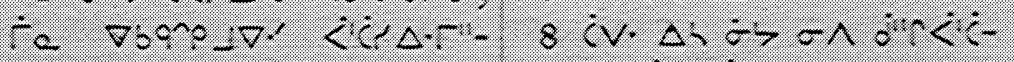

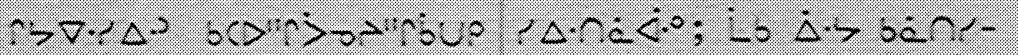

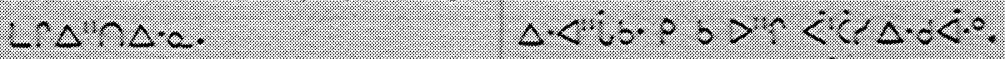

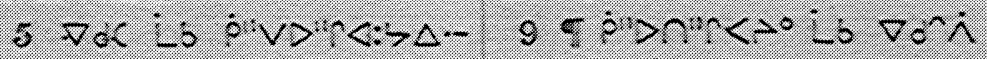

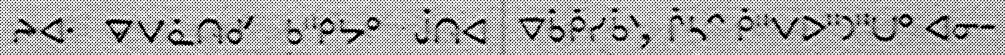

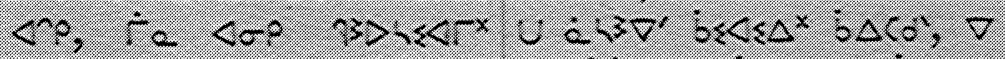

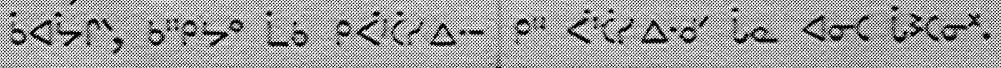

An opening page of the Cree New Testament (I 859) showing the syllabic character types, designed and cast by William Mavor Watts, which are known as Cree no. I (English), I 4 pt. 
$2 \frac{1}{2}$ percent was offered for cash. No mention was made of stereotyping. The Sub-Committee accepted this estimate. No supply of paper was required for this publication. The Sub-Committee was pleased to note: 'Surplus paper for Feejean used for this work. ${ }^{\text {II }}$ An example of the fourteen point syllabic character type to be used - Cree No. I (English) - was tipped into the Minute Book. ${ }^{\mathrm{I} 2}$ The types were of the same size and design as those of the fount originally prepared in I 853 for use at the Moose Church Missionary Station on James Bay. Full information concerning the casting and cost of the types for the Cree New Testament has not survived. The records of the printer and typefounder William Mavor Watts were lost in a fire which destroyed his premises in 1870 . It would seem that the cost of the types was included in composing costs.

The BFBs did not publish any scriptural translation without checking its accuracy. This was the task of the Editorial Sub-Committee. Early in January of I 859, a translational problem was identified. The term which had been used for the word 'baptize' was unacceptable to the BFBS. The Society was comprised of members of the Church of England and members of other denominations of Christians, i.e., nonconformists. Because of this, the word, term, or expression chosen for the translation of the word 'baptize' was not to suggest either dipping or sprinkling, but was to embrace both. ${ }^{\mathrm{I}} 3$ Mason knew of no word in the Cree language which 'would include both ideas of dipping and sprinkling,' but he did find a term which satisfied him and the Society. ${ }^{\mathrm{I} 4}$ The changes were considered at the meeting of the Editorial Sub-Committee held I9 January, ${ }^{15}$ but the Depository and Printing Sub-Committee did not order Watts to cancel the sheets with the offending translation until February $\mathrm{r} 4$, that is nearly a month later. ${ }^{16}$ Obviously, that Sub-Committee had authorized the commencement of printing before the Editorial Sub-Committee had fully investigated the faithfulness and suitability of the translation. It seems most likely that the translation had been sent for an opinion to George Barnley, formerly of the wMs, who had served at Moose Factory. Presumably, Barnley had also been consulted about the revisions put forward by Mason.

Two sheets were affected by the translation. The composition cost for 26 sheets, plus 2 corrected sheets, was $£ 85$.8.o. If the error was discovered before the presswork began, costs for five thousand copies of 26 sheets each, at 480 sheets to the ream, would have been $£ 67$.I 5.O. Should the entire edition have been pulled before the error was corrected, the cost for five thousand copies of 28 sheets would have been $£$ 72. I9.O. The second of the two possibilites is the more likely, since the offending translation occurred eighteen times in the first 4 half sheets of the Gospel of St. Matthew. Printing had undoubtedly begun by mid-December I 858 . The Secretary of the BFBS had written to Anderson on I December to say that the translation had 
been sent to Watts. ${ }^{17}$ The Depository and Printing Sub-Committee had indicated to Watts that it was desirable to complete the printing of the New Testament within four months, and Watts had told the Sub-Committee that he could meet this deadline by printing thirty-six pages each week. ${ }^{\mathrm{I} 8}$ This meant that Watts planned to print three sides per week, and he could certainly have finished the offending sheets by the time Mason retrieved them from the printer on 8 January $1859,{ }^{I 9}$ that is, after Watts had been printing for about three weeks.

The book was printed in double columns with a heading to each page, and was entirely in syllabic characters apart from the imprint and the colophon. Books printed in Rupert's Land at the field presses were also entirely in syllabic characters, but those printed by the BFBS were the only books printed in London for the use of the CMS which did not have their title-pages in English. The books printed for the Oblates in Montreal all have titlepages in French.

The Cree New Testament was completed in time to be sent to Rupert's Land in June of I 859 . The BFBS made a grant to the CMS of 2000 copies and to the wMs of 750 copies. ${ }^{20}$ The CMs engaged the vessel Kitty to carry supplies to the missionaries in the diocese. Unfortunately, the Kitty sank. The following year a second grant was made to the CMS of I 500 Cree Testaments, one of 700 to the wMS, and of 6 more to a correspondent in Red River. ${ }^{21}$ These grants all but exhausted the original supply of 5000 copies. The second shipment reached York Factory in August of I 860, but unaccountably, it was held in storage there for the winter of I 860-I86I. ${ }^{22}$ The problem of distribution was a serious one, and it was to worsen. Normally, mission goods and supplies were sent to Rupert's Land on the HBC's annual vessel. During the period examined, the Company charged for shipment a tariff of 75 percent of the prime cost of the goods, which was to include delivery inland. However, this charge did not cover storage costs when the Company failed to ship goods farther than York Factory. The cMs fared badly with the Company in the matter of bibles; trade-goods and supplies were necessities, and in the difficult circumstances which prevailed in Rupert's Land throughout the I860's, bibles were not among the first priorities for shipment inland.

The printing of the New Testament had not been long completed when the CMS asked the BFBS to publish an edition of five thousand copies of the Old Testament in syllabic characters. ${ }^{23}$ The size of the volume was of considerable concern to Mason, and he suggested that the book be printed in large octavo format using a type smaller than that used for the New Testament. Watts had designed and cast a fount of ten point syllabic character types-Cree No. 2 (long primer) - which had been used for the rubrics of the Moose Cree Prayer Book printed in London in I 859. Mason proposed its 


\section{ḃ}

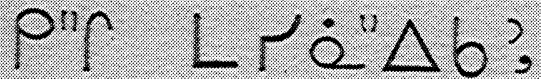

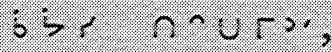

$+2$

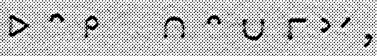

anvanata. ta onLtrv・ra。

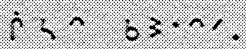

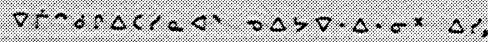

$$
\Delta \cdot \leqslant \leqslant \succ c: T ;
$$

$\leftrightarrow r \nabla \Delta \cdot P L^{\circ}$.

\section{$20 \times 0$ O N :}

PRINTED ROR TEE BRTISH ATD FOREIGX BTBLE SOCIETY.

1862

Title page of the Cree Old Testament (r86I). 


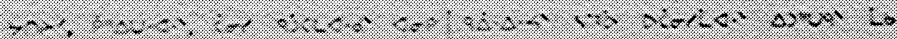

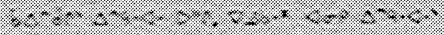

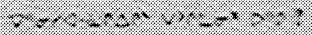

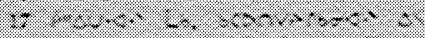

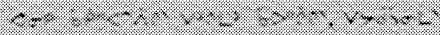

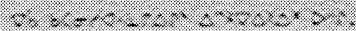

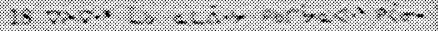

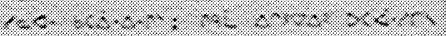

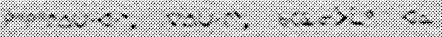

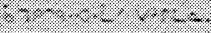

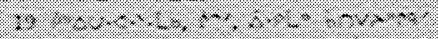

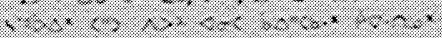

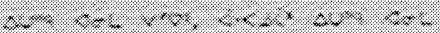

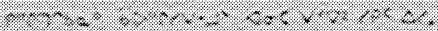

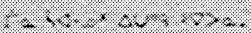

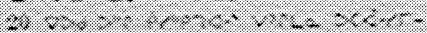

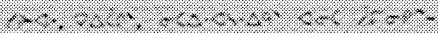

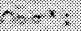

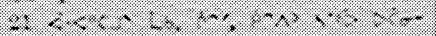

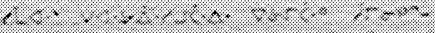

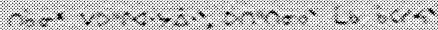

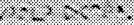

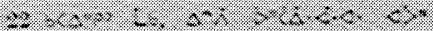

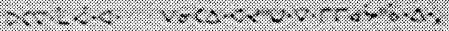

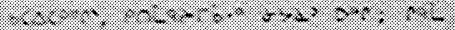

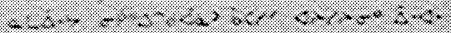

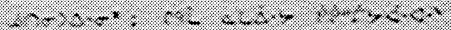

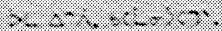

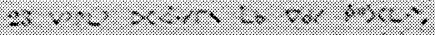

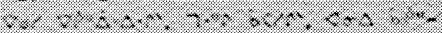

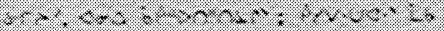

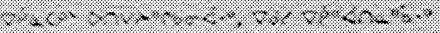

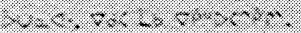

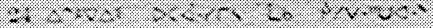

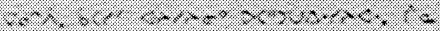

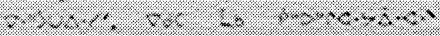

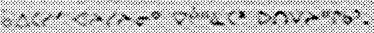

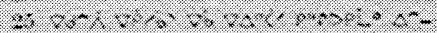

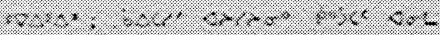

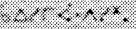

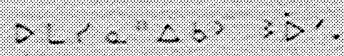

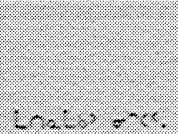

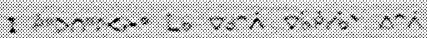

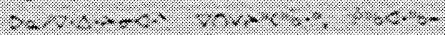

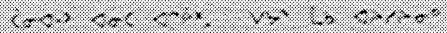

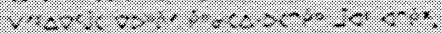

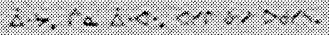

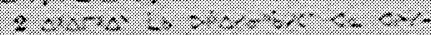

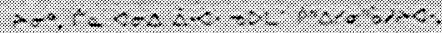

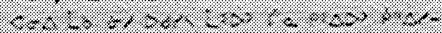

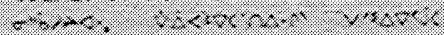

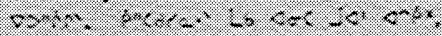

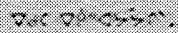

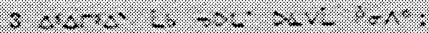

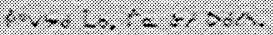

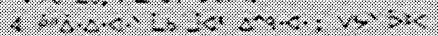

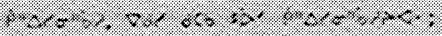

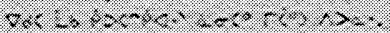

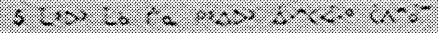

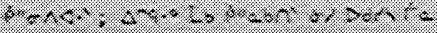

3.

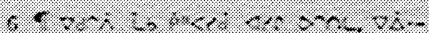

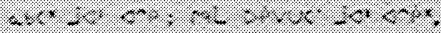

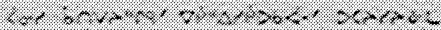

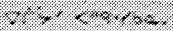

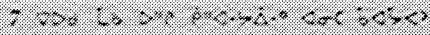

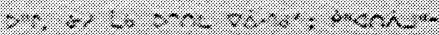

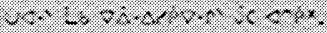

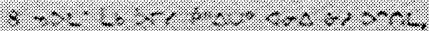

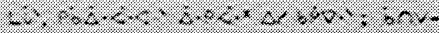

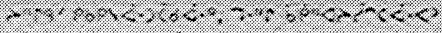

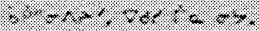

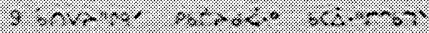

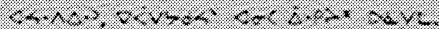

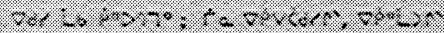
$2 \div$.

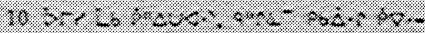

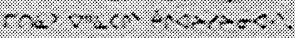

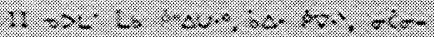

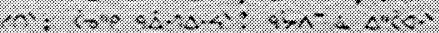

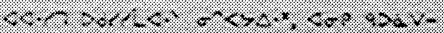

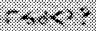

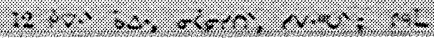

An opening page of the Cree Old Testament (I 86I). The types used are Watt's Cree no. 2 (long primer), Io pt. 


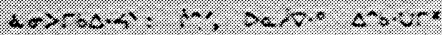
0.0 .6 .

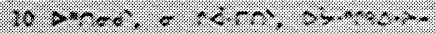

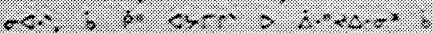
\$

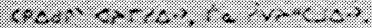

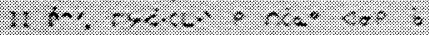

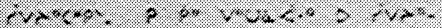

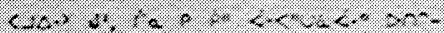

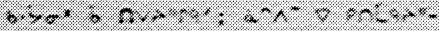

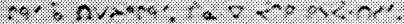

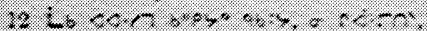

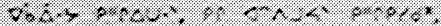
4. * ,

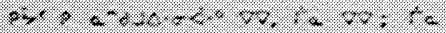

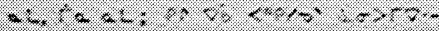

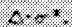

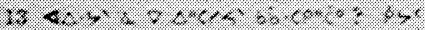

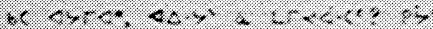

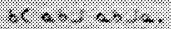

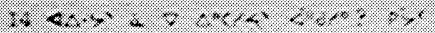

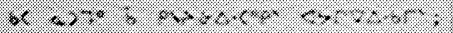

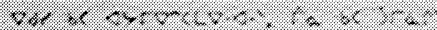
.

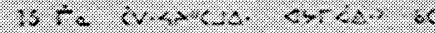

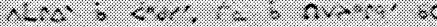

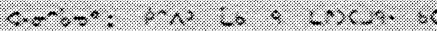

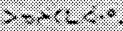

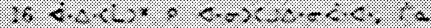

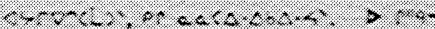

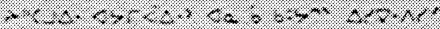

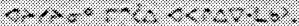

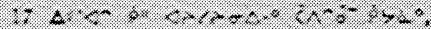

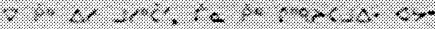

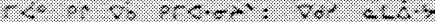

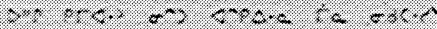

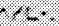

.

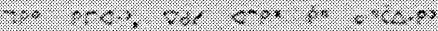
: $: 1$.

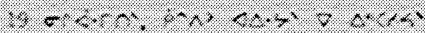

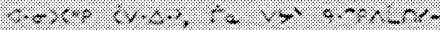
: $: 2:$

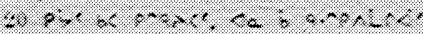

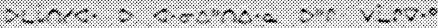
.

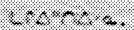

$$
\text { r. }
$$

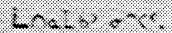

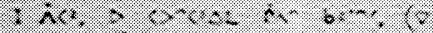

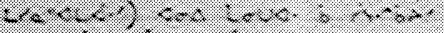

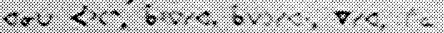

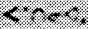

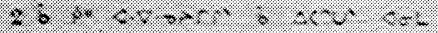

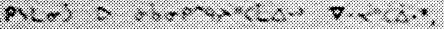

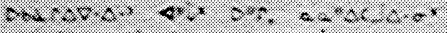

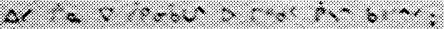

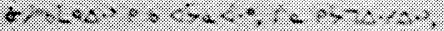

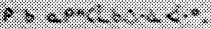

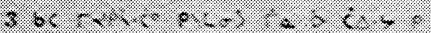

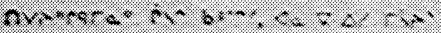

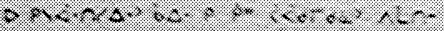

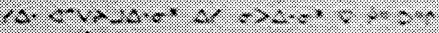

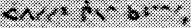

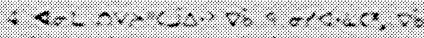

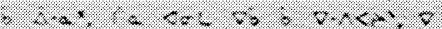

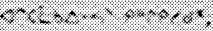

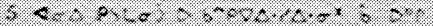

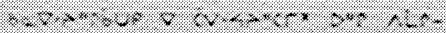

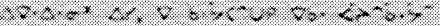
1.0 .0 .0$.

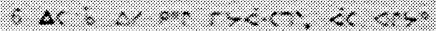

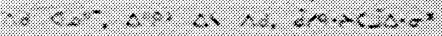

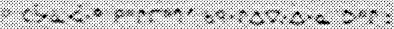

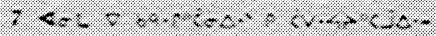

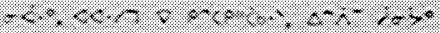

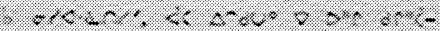

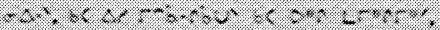

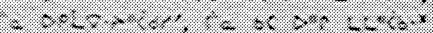

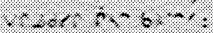

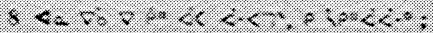

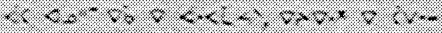

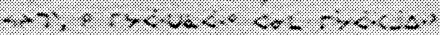

An opening page of the Cree New Testament (I862) showing the use of Cree no. 2 and boldface syllabic character types. 
use for the printing of the Old Testament as well as 'a large size character for the commencement of sentences, proper names and places. ${ }^{24}$ While the use of the ten point types was adopted, the use of the proposed larger types was not. By I 8 July I 859, the Depository and Printing Sub-Committee had received Watts' estimate for printing. He offered to compose the work, sixteen pages to the sheet, for $£ 4$.I I. 6 the sheet, with $5 /$ - per ream for presswork. He included 'an additional charge of $£ 25$ for casting a format of peculiar type commensurate with the extent of the work to be done. ${ }^{25}$ The composing cost for the Old Testament was $£ 247$.I. o for 54 sheets. Presswork for about 563 reams of 480 sheets each, was £ I 40 . I 5 .O.

Sophia Thomas Mason died in $\mathrm{I} 86 \mathrm{I}$, just as the printing of the Old Testament was completed. Despite her contribution to the translation and printing of the New and the Old Testaments, which Mason willingly acknowledged in his journals and letters, his name alone appears as translator on the title-page of each. Nor were the contributions of Steinhauer and Sinclair recognized in these publications.

Planning for the second edition of the New Testament began in September of $\mathrm{r} 86 \mathrm{I}$; it was to be a companion publication to the Old Testament, thus giving the Indians of Rupert's Land a complete Cree Bible. ${ }^{26}$ Samples of printing paper had been submitted by various suppliers, and the Depository and Printing Sub-Committee had ordered 200 reams at $8 / 6$ the ream. ${ }^{27}$ Watts offered to compose the work, at sixteen pages to the sheet, for £ 4. I I.6 the sheet, with 5/-per ream for presswork. There was to be an added charge for 'such new characters as may be introduced by the Editor and £ 2 [per] sheet for stereotyping.' As was the Old Testament, the I 862 edition of the New Testament was printed with ten point syllabic character types. Watts also designed and cast a fount of boldface ten point types. Thus Mason's expressed wishes, which were not adopted for the Old Testament, were carried out for the New. The first syllable of a proper name and of a place name was distinguished by the use of the heavier type. ${ }^{28}$ No record survives of either the order to make or to use these types. The composition of the New Testament of $\mathrm{r} 862$ cost $£ 85.15 \cdot 3$. Presswork, for 193 reams at 480 sheets to the ream, was $£ 48.5$. o for five thousand copies.

The printing of the New Testament was completed in February of 1862. Two separate books had been prepared: the Old Testament and the New Testament. Each has its own title-page and each its own signatures and pagination. However, they are generally found bound together in Persian Basil. As was the Cree New Testament of I 859, the complete Cree Bible was bound by Watkins of Gravel Lane, Southwark. The policy of the BFBS was to bind all of the books it printed. Nothing was ever sent to missions in sheets.

During the years of his sojourn in London, Mason had seen through the press fifteen books in syllabic characters for the use of the CMs among the native peoples of Rupert's Land. Apart from ten thousand copies of the New 
Testament and five thousand copies of the Old Testament, a total of eighteen thousand known copies of other devotional works, such as prayer books, catechisms, and hymnals, were also printed under his superintendence. This represents only six of the titles; five others were also printed, but the size of the editions is not known. These books were printed by Watts at the expense of the Society for Promoting Christian Knowledge and the CMS.

Mason returned to Rupert's Land in June of I 862. With him he took I 25 cases of the Cree Bible. Curiously, the BFBs made to the cMs a grant of one thousand Cree Old Testaments and three thousand New Testaments and to the wMs twelve Cree Bibles. ${ }^{29}$

Although the Old and the New Testaments are usually found bound together, the composition of this grant shows that they were not always bound together. There is a possibility that only two thousand copies of 'the complete Cree Bible' ever existed, that is assuming that one thousand copies of the complete Cree Bible were sent with two thousand copies of the New Testament. The number of Bibles in a case cannot be determined with certainty. Because of the composition of the grant, averaging is not reliable. However, it seems likely that there were no fewer than thirty-two books in each case.

Mason was asked to report on distribution in the Diocese of Rupert's Land. ${ }^{30}$ From the outset, he had difficulties in shipping bibles inland. All of the cases were still in storage at York Factory in December of 1862 , and he had to pay for storage as long as the boxes remained in the Company's warehouse. 'I offered to remove them to the Church, but I was told that the Church is the Company's property, and you will have to pay all the same..$^{3 \text { I }}$ He had hoped to move many of them inland the previous autumn, but it had been so dry a season 'that the Red River boats [had] for the first time in the living memory of man failed to reach [Fort York].' Boats for the interior left with not more than half a cargo. 'Under such unfavourable circumstances it was impossible' to ship any cases of Bibles. ${ }^{32}$ By September I 863 he still had on hand 97 of the 125 cases sent to York in I 862.33 In the autumn of 1863 he was required to pay £ıo.II.I I for a year's storage. He then arranged to transfer the remaining cases to his home, 'and there you may see Bibles in my study, cases of Bibles in my kitchen, dining-room and even my bedroom. ${ }^{34} \mathrm{He}$ was not required to pay for the storage of materials in the quarters supplied to him as chaplain to the $\mathrm{HBC}$ at York Factory.

In I 864, the year Anderson returned to England, Mason managed to send two hundred Bibles inland. The situation had not improved by the following year when he was able to send only two cases inland to the Wesleyans. ${ }^{35}$ With those sent to the Wesleyans, and those given to the Indians during the summer of I 865 , some two hundred to three hundred Bibles were distributed that year. No charge was made for Bibles given to impoverished 
Indians, but those capable of paying something were expected to do so. This appears to have been the policy of both the CMS and the BFBs. ${ }^{36}$ Mason continued to distribute Bibles as long as he remained in Rupert's Land, but he did not manage to distribute the entire supply he had brought back with him in I 862. He left the diocese in 1870 . The surrender of the HBC Territory to the Dominion of Canada in that year and the outbreak of the Riel Rebellion in I 869 appear to have stalled shipments. In I 869 he wrote:

I thought ten years might enable me to distribute the whole of the cases I brought out with me; and had there been no alteration in the position of the country I should not now have so many cases on hand... There are no boats to freight them at any price, even to Norway House. The number of cases disposed of since 1862 is $40 .^{37}$

NOTES

I Anderson was consecrated Bishop of Rupert's Land on Whit Tuesday, 29 May I849, in Canterbury Cathedral, as recorded by Eugene Stock in The History of the Church Missionary Society; Its Environment, Its Men and Its Work, 4 vols. (London:

Church Missionary Society, I 899-I9I61, 2: 3 I 2.

2 Henry Venn, Honorary Secretary of the CMs, to David Anderson, 8 March I 849, Church Missionary Society Home Correspondence Book, I 840-I 873, pp. 97-99, G/A CI/8, Church Missionary Society Archives (CMSA), London, U.K.

3 Fifty-fifth Report of the British and Foreign Bible Society; I859, p. 303.

4 Minutes of the Evidence Taken by the Select Committee on the Hudson's Bay Company (London, I859), p. 57.

5 Stock, History of the Church Missionary Society, 2: 3 I 4.

6 Proceedings of the Church Missionary Society ... I856-I857, p. I9I.

7 William Mason to James Constantine Pilling, 30 December I 886. Quoted by Pilling in his Bibliography of Algonquan Languages (Washington: Government Printing Office, I89I), p. 340 .

8 Dictionary of Canadian Biography, s.v. 'Thomas, Sophia (Mason).'

9 Venn to John Mee, Secretary of the BFBS, I9 October I 858, CMSA Home Correspondence Book, I 840-I 873, pp. 34-36, G/A CI/I4.

IO BFBS, Minutes of the Editorial Sub-Committee, 20 October I 858 , No. 5, p. I 8 I, Archives of the BFBS, London, U.K.

I I A revised edition of the New Testament in the language of Fiji had been published in I 858. See T.H. Darlow and H.F. Moule comps., Historical Catalogue of the Printed Editions of Holy Scripture in the Library of the British and Foreign Bible Society (London: Bible House, I903-I9II), no. 3630.

I 2 BFBS, Minutes of the Depository and Printing Sub-Committee, I November I 858, No. 6, p. 27.

I3 This requirement of the BFBS persists and is formally expressed in Rules for the Guidance of Translators, Revisers and Editors Working in Connection with the British and Foreign Bible Society (London, I9I7), p. I4.

I4 Mason to Mee, 8 January I 859, BFBS Editorial Correspondence, Inward, No. I, pp. 2O-2 I.

I5 BFBs, Minutes of the Editorial Sub-Committee, No. 5, p. I 94.

I 6 BFBS, Minutes of the Depository and Printing Sub-Committee, No. 6, p. 42.

I7 Mee to Anderson, I December I 858, BFBs Foreign Correspondence, Outward, I 858 , p. 377. 
I 8 BFBS, Minutes of the Depository and Printing Sub-Committee, I 3 December I 858 , No. 6, p. 35 .

I9 Mason to Mee, 8 January I 859 , BFBs Editorial Correspondence, Inward, No. I, pp. 20-2I.

20 Fifty-sixth Report of the British and Foreign Bible Society; I860, p. 70.

2 I Fifty-seventh Report of the British and Foreign Bible Society; I86I, p. 72.

22 Edwin A. Watkins to the Secretaries of the CMS, 3I December I 86I, CMS Class ' $C$ ' North West American Mission, Rupert's Land, C.I/o, PAC mf. reel A-98, Public Archives of Canada, Ottawa, Ont.

23 Venn to Mee, 2 June I 859, CMSA Home Correspondence Book, I840-1873, pp. 2092 IO, G/A CI/I4; BFBS, Minutes of the Editorial Sub-Committee, No. 6, pp. 44-45.

24 Mason to Mee, I6 June I859, BFBs Editorial Correspondence, Inward, No. I, p. I 20.

25 BFBS, Minutes of the Depository and Printing Sub-Committee, No. 6, p. 60.

26 The BFBS did not print the Apocrypha, nor would that Society support the publication of an edition of the Bible which included the Apocrypha.

27 BFBS, Minutes of the Depository and Printing Sub-Committee, 9 September I 86 I, No. 6, p. 167.

28 Mason to Mee, I6 June I859, BFBs Editorial Correspondence, Inward, No. I, p. I 20.

29 Fifty-ninth Report of the British and Foreign Bible Society; I863, p. 263.

30 BFBS to Mason, IO June I862, BFBS Foreign Correspondence, Outward, I862, p. I86.

3 I Mason to the Secretaries of the CMS, I December I862, CMSA William Mason, Letters, I 854-I870, C.CI/O 44 (I).

32 Sixtieth Report of the British and Foreign Bible Society; I864, p. 263.

33 Mason to the Secretaries of the CMS, September I863, CMSA, William Mason, Letters, I854-I 870, C.CI/o 44 (I).

34 Sixtieth Report of the British and Foreign Bible Society; I864, p. 262-263.

35 Mason to Venn, 26 September I865, CMSA William Mason, Letters, I854-I870, C.Ci/o 44 (I).

36 Sixtieth Report of the British and Foreign Bible Society; I864, p. 263-264.

37 Sixty-fourth Report of the British and Foreign Bible Society; I869, pp. 322-323.

British and Foreign Bible Society Archives will be deposited at Cambridge University Library in I 985 . Church Missionary Society Archives are being transferred to the University of Birmingham, and documents relating to Rupert's Land will be available for consultation there in 1985 . These holdings have been described by Miss Rosemary Keen, CMs Archivist, in Catalogue of Papers of the Missions of East Asia (Group I) Committee, Vol. I, Canada Missions I82I-I930 (London: Church Missionary Society, I983). Researchers should write to the University to advise staff as to arrival time and the material they wish to consult. Material from the CMs Archives is available on microfilm at the Public Archives of Canada. Class ' $\mathrm{C}$ ' North West America Mission includes letterbooks, mission books, and original papers, on reels A75-AI 5O. A finding aid has been provided.

All illustrations are courtesy of the National Library of Canada / Bibliothèque nationale du Canada. 